\title{
Odkrywanie warstw historii. Centrum Żydowskie "Oszpicin" i Park Pamięci Wielkiej Synagogi w Oświęcimiu
}

\author{
Bartosz Haduch \\ https://orcid.org/0000-0001-7033-5058 \\ bartoszhaduch@hotmail.com \\ Wydziat Architektury i Sztuk Pięknych, \\ Krakowska Akademia im. Andrzeja Frycza Modrzewskiego
}

Streszczenie: Artykuł przedstawia historię powstania dwóch projektów - Centrum Żydowskiego "Oszpicin” i Parku Pamięci Wielkiej Synagogi w Oświęcimiu z perspektywy projektanta. Realizacje omawiane są w szerszych kontekstach - architektonicznym, urbanistycznym, historycznym i kulturowym. Szczegółowo zaprezentowane są zarówno założenia projektowe, nawiązania oraz inspiracje, ale również bogata i skomplikowana historia konkretnych miejsc. Przedstawione realizacje są przykładem wpisania współczesnych rozwiązań architektonicznych w historyczną tkankę miejską.

Słowa kluczowe: architektura, urbanistyka, sztuka, historia, dziedzictwo kulturowe

\section{Wstęp}

Celem artykułu jest przedstawienie powiązanych ze sobą realizacji Centrum Żydowskiego "Oszpicin" i Parku Pamięci Wielkiej Synagogi w Oświęcimiu oraz wielowątkowych inspiracji leżących u genezy powstania tych dwóch projektów. Obie koncepcje zostały przygotowane przez pracownię NArchitekTURA (Bartosz Haduch, Łukasz Marjański) we współpracy z Imaginga Studio (Magdalena Poprawska), kuratorem części wystawowej był Artur Szyndler, a kierownikiem całego przedsięwzięcia - dyrektor instytucji Tomasz Kuncewicz.

\section{Centrum Żydowskie „Oszpicin”}

Zrealizowany w pierwszym etapie projekt nowej ekspozycji i aranżacji wnętrz Centrum Żydowskiego w Oświęcimiu - Auschwitz Jewish Center ${ }^{1}$ (2013-2015) bazuje na materialnych i niematerialnych działaniach, definiujących na nowo obraz zabytkowej architektury. Kompleks historycznych budynków i przestrzeni (plac ks. Jana Skarbka², 
dawny dom Kornreichów i Dattnerów ${ }^{3}$, synagoga Chewra Lomdej Misznajot ${ }^{4}$ i dom rodziny Klugerów ${ }^{5}$ ) został zintegrowany za pomocą zróżnicowanych środków architektonicznych i spójnego systemu identyfikacji wizualnej. Na zewnątrz część ścian Centrum obsadzono różnymi gatunkami bluszczy, a przed głównym wejściem zaplanowano podłużną ławkę o zmiennej wysokości (dla osób o różnym wieku i wzroście). Historyczne wnętrza zostały "wyczyszczone” ze zbędnych elementów i odrestaurowane, a wystawę pt. „Oszpicin. Historia żydowskiego Oświęcimia" ${ }^{6}$ podzielono tematycznie na kilka działów eksponowanych w poszczególnych pomieszczeniach - „Początki (do roku 1772)”, "Galicja (1772-1918)”, „Między Wojnami (1918-1939)”, „Zagłada (1939-1945)”, „Polska Ludowa (1945-1989)" i "Pamięć". W założeniach autorów ekspozycji, miała być ona uzupełnieniem i swoistą przeciwwagą dla pobliskiego Miejsca Pamięci i Muzeum Auschwitz-Birkenau ${ }^{7}$, prezentując głównie pozytywną tożsamość i codzienne życie miasta, w którym splatały się losy wielu ludzi, religii i kultur ${ }^{8}$. W ramach nowego projektu architektonicznego wszelkie ingerencje w zabytkową tkankę powstały w szacunku dla delikatnej i trudnej historii oraz wyjątkowego charakteru miejsca.

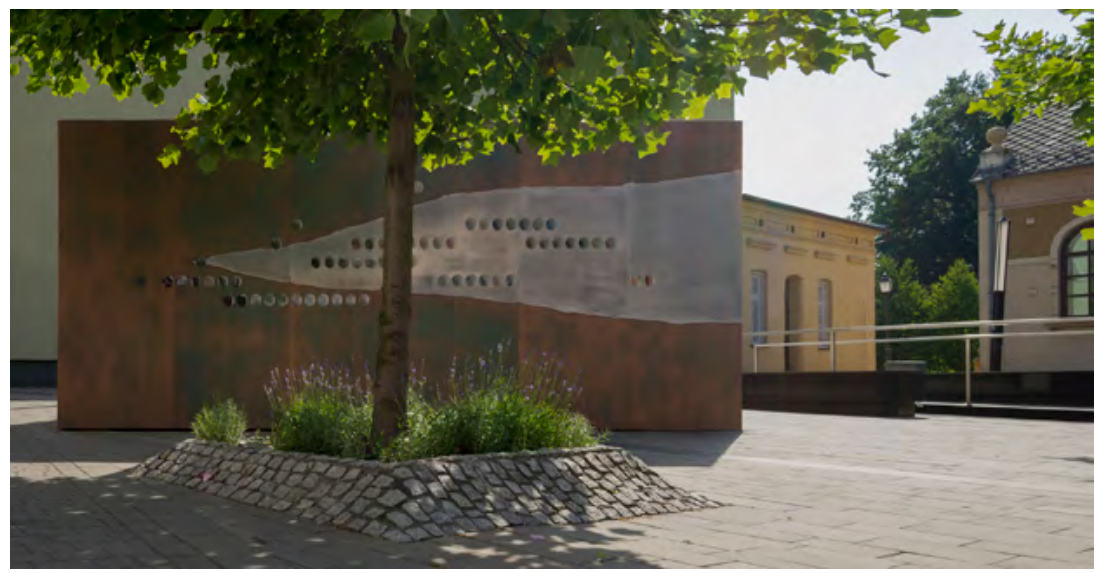

Ryc. 1. Element ekspozycyjny na placu przed wejściem do Centrum Żydowskiego w Oświęcimiu. Fotografia: Bartosz Haduch.

Większość wnętrz Centrum Żydowskiego utrzymano w jasnej kolorystyce. Część ścian poprzecinano pasmami wykorzystującymi różne sposoby ekspozycji (historyczne przedmioty i dokumenty, fotografie, filmy, projekcje itp.), uzyskując efekt wielofunkcyjnej wstęgi otaczającej widza. Ten schemat został podkreślony przez pośrednie oświetlenie wykorzystane w salach i gablotach. Podobna linia świetlna, ukryta w „przeciętym” sklepieniu kolebkowym w holu głównym, podkreśla oś łączącą strefę wejściową, poszczególne pomieszczenia i otwarty taras z widokiem na pobliski zamek w Oświęcimiu?

Ważnym motywem kształtowania ekspozycji i aranżacji wnętrz były różne interpretacje "odkrywania historii". Tuż po wejściu do Centrum trafiamy na niestandardowy element ekspozycyjny pokryty metalowymi panelami.

3 Przed II wojną światową w budynku tym mieszkały dwie rodziny żydowskie - Kornreichów i Dattnerów. Od 1998 roku obiekt jest własnością Centrum Żydowskiego w Oświęcimiu, a w jego wnętrzach mieszczą się obecnie sale ekspozycyjne oraz biura tej instytucji. W poziomie przyziemia jest on połączony z synagogą Chewra Lomdej Misznajot.

4 Synagoga Chewra Lomdej Misznajot to jedyna żydowska świątynia, która nie została całkowicie zniszczona podczas II wojny światowej (destrukcji uległy głównie wnętrza i wyposażenie, natomiast zewnętrzne mury ocalały). Budowę obiektu rozpoczęto około 1913 roku i pełnił on swoją funkcję do połowy 1939 r. Po zakończeniu wojny grupa ocalałych Żydów wykorzystywała tę przestrzeń do zgromadzeń modlitewnych, natomiast z biegiem czasu systematycznie opuszczali oni Oświęcim i Polskę. W latach 70. XX wieku ówczesne władze znacjonalizowały budynek, po czym zlokalizowano w nim hurtownię dywanów. W 1998 roku budynek zwrócono gminie wyznaniowej w Bielsku-Białej, następnie został on przekazany lokalnemu Centrum Żydowskiemu, którego siedzibą jest do dzisiaj. Zabytkowy obiekt gruntownie odrestaurowano pod koniec ubiegłego wieku i został on udostępniony zwiedzającym we wrześniu 2000 roku.

5 Dom ostatniego żydowskiego mieszkańca Oświęcimia - Szymona Klugera (1925-2000) został zaadaptowany na potrzeby powiązanej z Centrum Żydowskim kawiarni - Café Bergson.

6 B. Haduch, T. Kuncewicz, M. Poprawska, A. Szyndler, Oszpicin. Historia żydowskiego Oświęcimia, Centrum Żydowskie w Oświęcimiu, Oświęcim 2015.

7 http://auschwitz.org.

8 W 1939 roku Żydzi stanowili ponad połowę mieszkańców Oświęcimia, po wojnie do miasta powróciło ich zaledwie 186, a większość z nich wyjechała w kolejnych dekadach - głównie za granicę. Dużą część społeczności lokalnej stanowili też Romowie (naprzeciw Parku Pamięci Wielkiej Synagogi znajduje się obecnie siedziba Stowarzyszenia Romów w Polsce).

9 Okazała budowla, której historia sięga przełomu XI i XII wieku, od 2010 roku jest siedzibą miejskiego muzeum. 
Smuga przeszlifowana w miedzi na wysokości wzroku ukazuje poszczególne fazy starzenia się materiału - od refleksyjnej płaszczyzny przypominającej lustro, poprzez złoto i brąz, aż po matowy seledyn. Inspiracją dla takiego potraktowania materiału były historyczne eksponaty znajdujące się w kolekcji Centrum - kandelabry, menory, świeczniki, lampy itp..$^{10} Z$ kolei efekt lustrzanej płaszczyzny ma sugerować konfrontację teraźniejszości z historią. Poprzez perforacje w miedzianej bryle zwiedzający mogą oglądać wyświetlany cyklicznie film, przedstawiający życie codzienne dawnych mieszkańców Oświęcimia. W przerwach między projekcjami, we wnętrzu ekspozytora pojawiają się ciekawe efekty świetlne, zmieniające się w zależności od pory dnia i natężenia światła. Promienie wpadają do wnętrza przez wycięte laserowo litery, układające się w dawną nazwę miasta - Oszpicin (ten napis, w trzech językach - polskim, angielskim i hebrajskim, stał się nieoficjalnym logotypem projektu i został powielony w różnych elementach aranżacji).

Podobny, "quasi-archeologiczny" efekt odkrywania historii miejsca i materiału pojawia się również w elemencie ekspozycyjnym w pomieszczeniu łączącym dwa działy tematyczne - "Polska Ludowa" i "Pamięć". Tym razem pasmo lustrzane pojawia się na pordzewiałej blasze, eksponując poprzez okrągłe perforacje odręcznie pisane listy lokalnej społeczności.

Szpiczaste kształty rzutów opisywanych elementów symbolizują zdeformowane i zdekonstruowane ramiona Gwiazdy Dawida, a kierunki wskazywane przez poszczególne formy ilustrują konkretne miejsca emigracji narodu żydowskiego. Te graniastosłupy trójkątne z różnych rodzajów blachy sugerują kierunek zwiedzania, akcentują też początek i koniec ekspozycji.

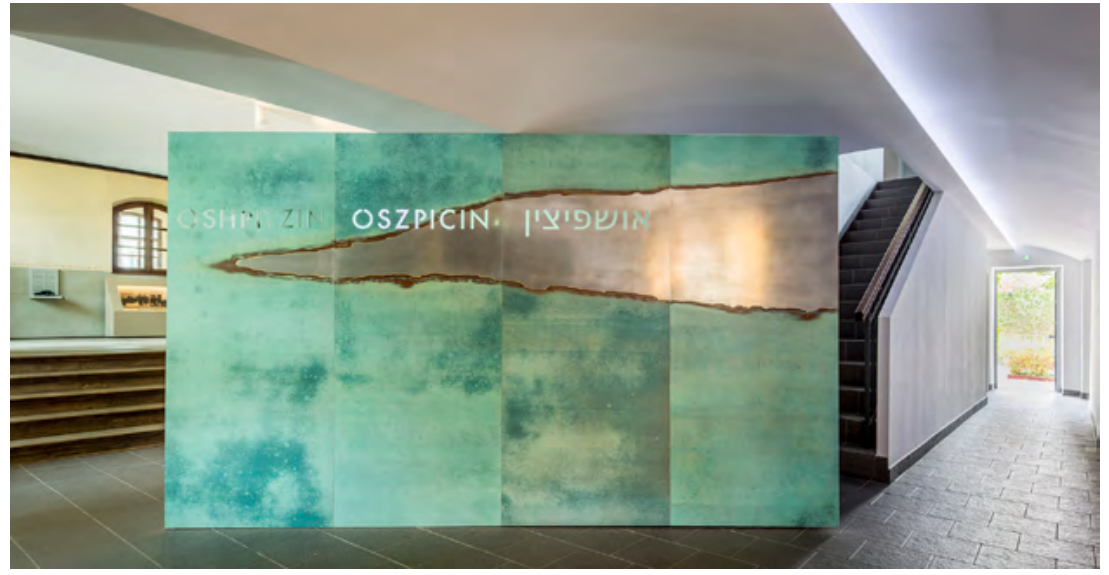

Ryc. 2. Strefa wejściowa Centrum Żydowskiego w Oświęcimiu. Fotografia: Jakub Certowicz.

W kolejnych pomieszczeniach nowe interwencje dostosowane są do zachowanych elementów historycznej architektury. W sali „Początki" podłużna gablota i wolno stojąca balustrada niejako "wyrastają" ze starych drewnianych schodów. W tym miejscu eksponowane są m.in. historyczna płyta nagrobna i grafiki z modlitewnika Machzor ke-minchag kahal kadosz Aszkenazim. W położonych na wyższym poziomie dwóch pomieszczeniach synagogi Chewra Lomdej Misznajot ingerencje architektoniczne zostały ograniczone do minimum. W tzw. żeńskiej części wszystkie eksponaty związane z częściami "Galicja” i "Między Wojnami” umieszczono w trzech podłużnych gablotach, dostosowanych kolorystycznie do historycznej drewnianej posadzki. Ze starych murów zdjęto wszelkie obrazy i plansze, eksponując pierwotną formę wnętrza i fragmentarycznie odsłonięte zdobienia. Poprzez celowe pozostawienie na ścianach nieregularnych plam, odcisków starych ram i różnych odcieni kolorystycznych uzyskano unikalną graficzną mozaikę, wzbogacaną o refleksy świetlne z wysokich okien synagogi i projekcje multimedialne. To połączenie surowego świadectwa czasu i historii z działaniami niematerialnymi (wzbogaconymi o muzykę w tle) tworzy rodzaj współczesnej interpretacji architektonicznego ornamentu. Układ kolejnego wnętrza - głównej części synagogi został praktycznie niezmieniony. W tym miejscu cyklicznie odbywają się koncerty, spektakle i uroczystości upamiętniające ważne dla społeczności żydowskiej wydarzenia. 


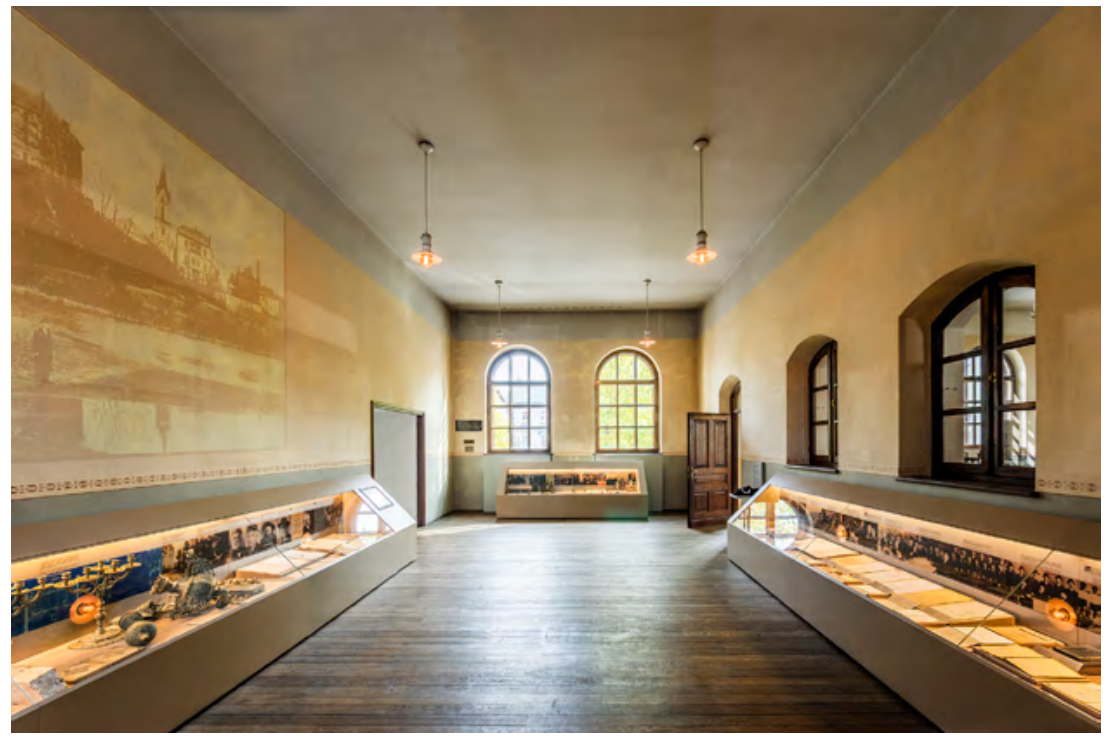

Ryc. 3. Ekspozycja we wnętrzach synagogi Chewra Lomdej Misznajot. Fotografia: Jakub Certowicz.

Nieco inny charakter mają dalsze sale. Wąskie pomieszczenie ilustrujące tematykę działu „Zagłada” bazuje na płynnie zagiętej ścianie z wąskim wycięciem na wysokości wzroku, podkreślając efekt wielofunkcyjnej wstęgi przecinającej kameralne, jasne wnętrze. Analogiczną zasadę wykorzystano też w sali „Pamięć", gdzie dziewięć interaktywnych monitorów z symultaniczną instalacją multimedialną otacza widza obrazem, światłem i dźwiękiem $^{11}$. Nawet szatnia przy wyjściu na zewnętrzny taras podąża za podobnym schematem - rząd ruchomych wieszaków przecina na jednym poziomie trzy ściany niewielkiej wnęki.

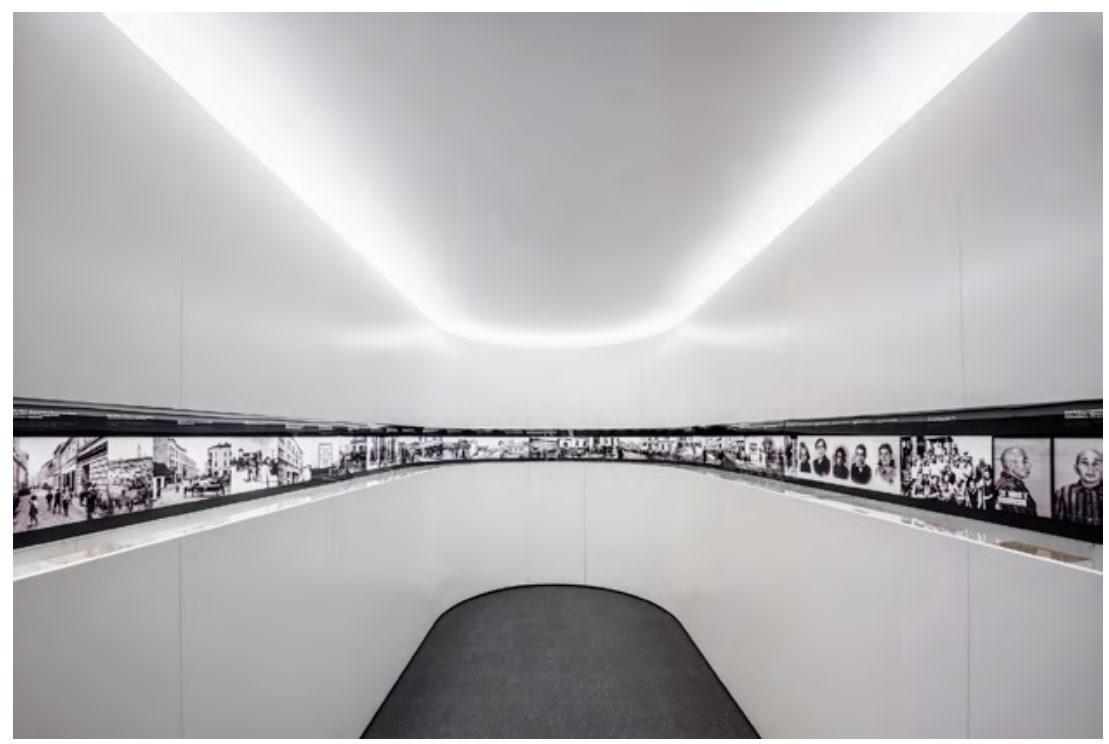

Ryc. 4. Sala ekspozycyjna „Zagłada (1939-1945)". Fotografia: Jakub Certowicz.

Oprócz elementów architektonicznych, specjalnie na potrzeby nowej aranżacji wnętrz Centrum zaprojektowano wszystkie gabloty, meble, elementy graficzne i niestandardowe detale. W części z nich wykorzystano ciekawe zjawiska optyczne, związane z użyciem szkieł i soczewek o różnych rozmiarach (np. w zabytkowych drzwiach wejściowych). W przyszłości elementy nawiązujące do aranżacji wnętrz mają pojawić się również w przyległym do budynków Centrum Żydowskiego ogrodzie, ale też w przestrzeniach publicznych Oświęcimia, rozszerzając zakres działania tej instytucji oraz popularyzując jej ofertę kulturalną i edukacyjną. Pierwszym, zrealizowanym 
w 2015 roku na placu ks. Jana Skarbka, jest pokaźny ekspozytor z instalacją świetlną wykorzystującą fragment wiersza Wisławy Szymborskiej ${ }^{12}$ oraz komiks pt. "Oświęcimskie historie" autorstwa Tomasza Bereźnickiego (w 2016 roku został on wydany w formie książki ${ }^{13}$ ).

Projekt Centrum Żydowskiego "Oszpicin" ma być pretekstem do wyjątkowego, sensorycznego postrzegania i doświadczania architektury oraz historii. Nowe wnętrza mają działać na wszystkie zmysły, od zaskakujących układów przestrzennych, po zmienne efekty związane z działaniem światła i cienia, precyzyjny dobór materiałów i najmniejszy detal. To wszystko powinno sprzyjać nieśpiesznemu, wnikliwemu i fascynującemu procesowi odkrywania kolejnych warstw historii - ludzi i miejsc.

\section{Park Pamięci Wielkiej Synagogi (Ścieżki życia)}

Centrum Żydowskie w Oświęcimiu zajmuje się nie tylko działalnością ekspozycyjną, edukacyjną i kulturalną w obrębie opisywanych wcześniej budynków. Instytucja opiekuje się również dwoma ważnymi historycznie miejscami w centrum miasta. Pierwsze z nich, to cmentarz żydowski ${ }^{14}$, drugie, to teren po nieistniejącej już bożnicy w pobliżu bulwarów rzeki Soły. To właśnie w tej malowniczej lokalizacji 28 listopada 2019 roku, 80 lat po zburzeniu świątyni przez hitlerowców, otwarto Park Pamięci Wielkiej Synagogi (2018-2019). Głównym elementem architektonicznym tej przestrzeni stał się odpad przemysłowy - płyty z szarego piaskowca z niezliczoną ilością nieregularnych nacięć. Ten unikatowy materiał symbolizuje ruiny nieistniejącej już Wielkiej Synagogi i ścieżki życia wielokulturowej społeczności, krzyżujące się niegdyś w tym miejscu.

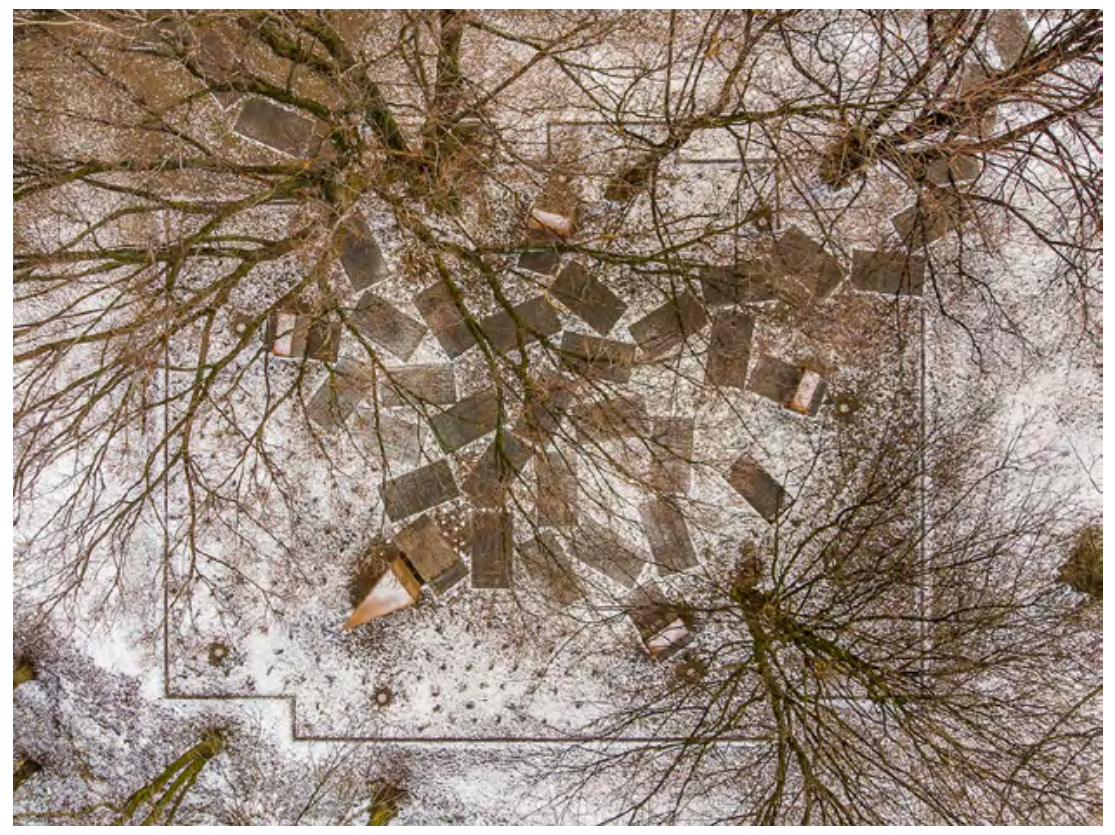

Ryc. 5. Widok z góry Parku Pamięci Wielkiej Synagogi w Oświęcimiu. Fotografia: Piotr Strycharski.

12 Cytat „Kiedy wymawiam słowo Przyszłość, pierwsza sylaba odchodzi już do przeszłości” z wiersza pt. „Trzy słowa najdziwniejsze” z tomu „Widok z ziarnkiem piasku" (1996)

13 T. Bereźnicki, Oświęcimskie historie, Centrum Żydowskie w Oświęcimiu, Oświęcim 2016.

14 Cmentarz żydowski w Oświęcimiu zajmuje teren o powierzchni około 1,7 ha u zbiegu ulic Dąbrowskiego i Wysokie Brzegi. W jego obrębie znajduje się ponad tysiąc macew - najstarsze z XVIII wieku, a ostatni pochówek odbył się w tym miejscu w 2000 roku. 
Wielka Synagoga w Oświęcimiu ${ }^{15}$ (znajdująca się dawniej przy obecnej ulicy Berka Joselewicza) była największą bożnicą żydowską w tym mieście. Na początku Il wojny światowej została zburzona przez niemieckich żołnierzy. W 1941 roku jej pozostałości zostały rozebrane i już nigdy nie została odbudowana w pierwotnej formie. Przez kolejne dekady obszar ten porosła zieleń, a pojedyncze drzewa przybrały pokaźne rozmiary, przykrywając gęstymi koronami schowane pod ziemią ruiny. W 2018 roku, podczas pierwszych rozmów dotyczących upamiętnienia dawnej świątyni, wstępnie planowano postawienie w tym miejscu tylko jednego ekspozytora (powiązanego z wystawą w pobliskim Centrum Żydowskim), jednak finalnie architekci przekonali inwestora do kompleksowego zagospodarowania całego tego terenu.

Odniesienia do zburzonej świątyni pojawiają się w nowym projekcie w różnych formach. Obrys rzutu dawnej synagogi zaznaczony jest wąskim krawężnikiem, oddzielając wnętrze parku od otaczającej go gęstej zieleni. Główne wejścia dostosowane są do pobliskich ciągów komunikacyjnych i kadrują dwie dominanty urbanistyczne - Kościół Wniebowzięcia Najświętszej Maryi Panny oraz Sanktuarium Matki Bożej Wspomożenia Wiernych. Całość założenia otwiera się na malowniczą panoramę bulwarów rzeki Soły. Głównym elementem zagospodarowania parku jest mozaika czterdziestu płyt z szarego piaskowca. Ich nieregularny układ ma symbolizować pozostałości po dawnej synagodze (jej podłoga była wykonana z podobnego materiału). Płyty prowadzą do poszczególnych elementów parku - ekspozytora przedstawiającego historię synagogi (nawiązującego stylistycznie do wcześniejszego projektu Centrum Żydowskiego), "studni” z historyczną posadzką (planowanej w kolejnym etapie inwestycji), sadzawki wodnej, ławek z blachy Corten oraz żyrandola (będącego kopią artefaktu znalezionego w tym miejscu podczas prac archeologicznych). Wymiary, kształty i kolory zastosowanych form są powiązane nie tylko z tradycją żydowską, ale też z uniwersalną symboliką, czytelną w obrębie różnych wyznań i kultur. Przestrzeń ma charakter otwarty i pozwala na różne sposoby użytkowania, upamiętniania oraz interpretacji.

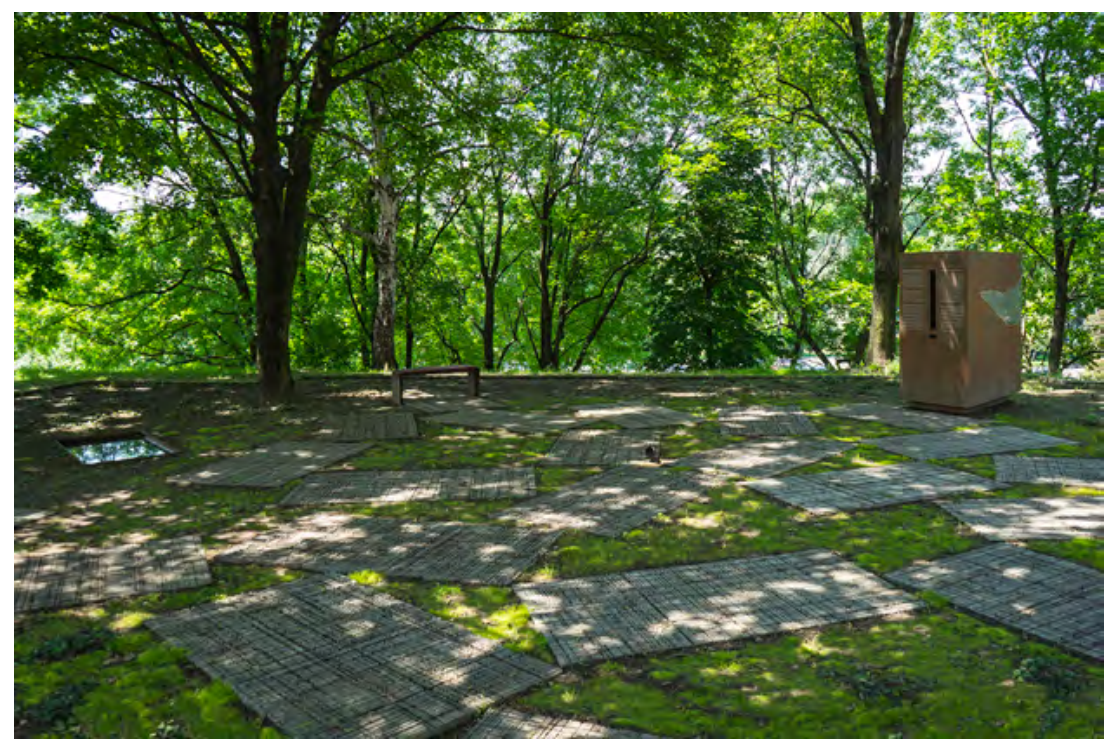

Ryc. 6. Wnętrze Parku Pamięci Wielkiej Synagogi. Fotografia: Bartosz Haduch.

Ilustracja tytułowej idei „ścieżek życia” przejawia się głównie w formie unikatowego rozwiązania materiałowego. Moduły z szarego piaskowca o wymiarach $120 \times 220 \mathrm{~cm}$ zdobią "reliefy” złożone z niezliczonych żłobień o zmiennych głębokościach. Te linie wycięte w kamieniu tworzą rodzaj niepowtarzalnych "płaskorzeźb", zmieniających swój wizerunek w zależności od kąta padania światła i jego intensywności, czy też warunków atmosferycznych - deszczu, śniegu itp. Co ciekawe, ten geometryczny wzór nie jest efektem pracy architektów wykorzystujących najnowsze technologie, lecz w dużym stopniu dziełem przypadku. W kamieniołomie płyty

15 Wielka Synagoga w Oświęcimiu została wzniesiona w latach 1863-1873 (na miejscu starszej bożnicy żydowskiej), a później, na przełomie 1899 i 1900 roku przebudowana według projektu Karola Korna, łączącego elementy neoromanizmu, neogotyku oraz stylu mauretańskiego. Świątynia mogła pomieścić prawie dwa tysiące osób, a centralną salę modlitw otaczały trzy galerie dla kobiet. Kopie dokumentacji projektowe oraz ocalałe elementy wystroju wnętrza synagogi (pochodzące z prac archeologicznych z 2004 roku) można oglądać na wystawie w pobliskim Centrum Żydowskim. 
te służyły jako podstawy do cięcia mniejszych formatów i nikt wcześniej nie wpadł na pomysł zastosowania ich w budownictwie. Są one odpadem przemysłowym, ponownie wykorzystanym i "przywróconym do życia", niejako w geście sprzeciwu wobec nadmiernej eksploatacji bogactw naturalnych.

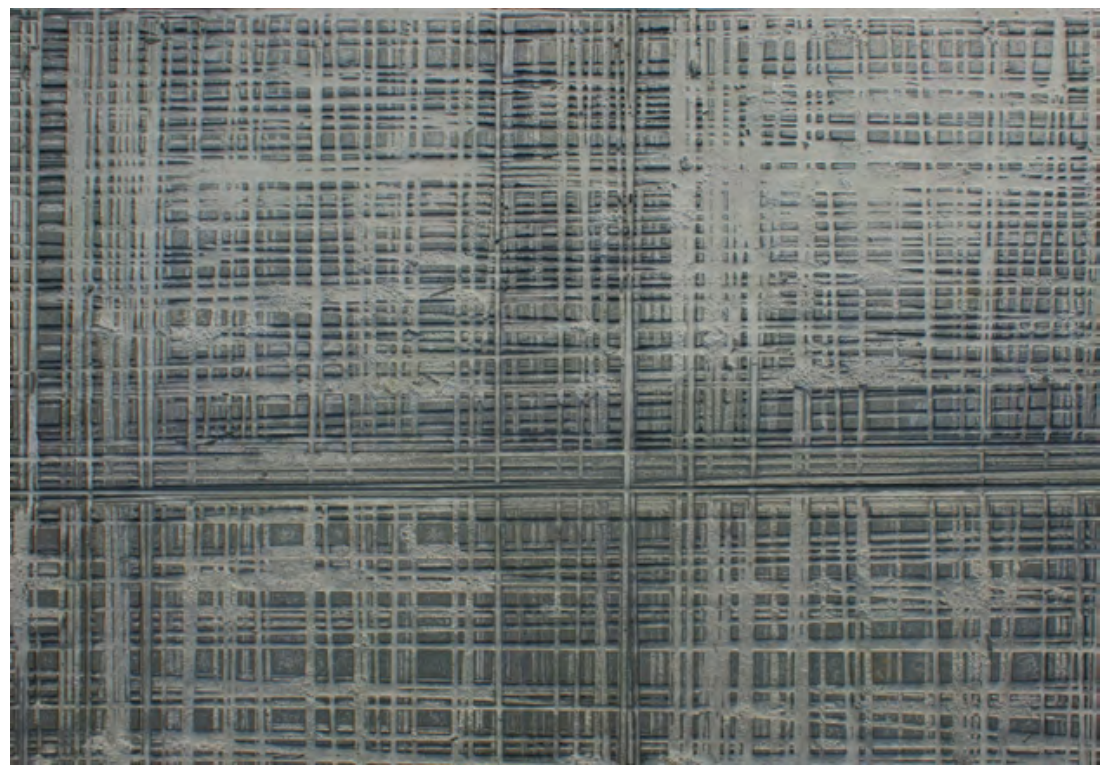

Ryc. 7. Detal płyty z szarego piaskowca, zastosowanej w posadzce Parku Pamięci. Fotografia: Bartosz Haduch.

Przenikające się wzajemnie linie nacięć kamienia mają też pewien wymiar symboliczny. Bez wyraźnego początku i końca, zdają się zmierzać ku nieskończoności. Ta gęsta siatka linii może przywodzić na myśl ścieżki ludzkiego życia, które czasem ledwie się przecinają, a kiedy indziej łączą, by podążać dalej razem. Pozornie abstrakcyjna mozaika może przypominać również nieistniejący już układ urbanistyczny przedwojennego miasta - jego ulic, chodników i zabudowy. Ta "wycięta w kamieniu” historia Oświęcimian, Wielkiej Synagogi i pozostałych po niej ruin została stworzona dla podtrzymania pamięci o przeszłości, z przestrogą na przyszłość, ale też z myślą o pięknym celebrowaniu teraźniejszości. Być może i to miejsce za kilkaset lat stanie się tajemniczym znaleziskiem archeologicznym? Wszak ludzkość od wieków czerpie wiedzę o zamierzchłych czasach z ilustracji i tekstów uwiecznionych w kamieniu. Ciekawe, jak w odległej przyszłości będzie interpretowane przesłanie ukryte w czterdziestu płytach Parku Pamięci?

\section{Zakończenie}

Prezentowane realizacje Centrum Żydowskiego „Oszpicin” i Parku Pamięci Wielkiej Synagogi w Oświęcimiu można uznać za próbę adekwatnego, subtelnego i niedosłownego połączenia współczesnej architektury ze skomplikowaną historią - miasta, budynków i ludzi. Te skromne, kameralne projekty stały się przedmiotami wielu publikacji ${ }^{16}$ i zostały wyróżnione licznymi nagrodami oraz nominacjami ${ }^{17}$. Wizja architektów, która ze skali wnętrza rozrosła się do punktowych interwencji w skali urbanistycznej, ma wciąż szansę na kontynuację i dalszy rozwój, co być może stanie się pretekstem i inspiracją dla kolejnego naukowego artykułu.

16 Centrum Żydowskie „Oszpicin” i Park Pamięci Wielkiej Synagogi w Oświęcimiu zostały opublikowane w międzynarodowych i ogólnopolskich magazynach oraz portalach internetowych: Designboom, Dezeen, Archdaily, Wallpaper, Interior Design, Intro, Designverse, WhiteMad, Architektura \& Biznes, Architektura-Murator i ARCH.

17 Park Pamięci Wielkiej Synagogi otrzymał następujące nagrody i wyróżnienia: nominacja do nagrody Unii Europejskiej w dziedzinie współczesnej architektury - Mies van der Rohe Award (2021), Nagroda Witkiewicza 2020 - I miejsce w kategorii "przestrzeń publiczna" (2020), I miejsce w kategorii „przestrzeń publiczna w zieleni” w konkursie Towarzystwa Urbanistów Polskich na najlepiej zagospodarowaną przestrzeń publiczną w Polsce (2021), finałowa pula 49 projektów w ramach ogólnopolskiego konkursu „Życie w Architekturze 2020” (2020) Tytuł "Lider Małopolski 2020" za najlepsze przedsięwzięcie roku w Małopolsce (2020), wyróżnienie w ogólnopolskim konkursie PLGBC Green Building Awards 2020 (2020), wyróżnienie w V edycji Nagrody im. Jerzego Regulskiego w kategorii "realizacja dzieła” (2021), finał konkursu Polska Architektura XXL portalu Sztuka Architektury (2021) i nominacja w międzynarodowym konkursie The European Property Awards (2021). 


\section{Bibliografia}

[1] Arczyńska M., Park pamĕti v Osvětimi, w: Intro 14/2021, Hradec Králové 2021, s. 96-101.

[2] Bereźnicki T., Oświęcimskie historie, Centrum Żydowskie w Oświęcimiu, Oświęcim 2016.

[3] Forczek-Brataniec U., Haduch B., Lewicki P., Łatak K., Żylski T., Park Pamięci w Oświęcimiu, w: Architektura-Murator 02(305)/2020, s. 22-32.

[4] Grąbczewski O., Centrum Żydowskie w Oświęcimiu, w: Architektura-Murator 09(264)/2016, Warszawa 2016, s. 86-89.

[5] Haduch B., Kuncewicz T., Poprawska M., Szyndler A., Oszpicin. Historia żydowskiego Oświęcimia, Centrum Żydowskie w Oświęcimiu, Oświęcim 2015.

[6] Zemła K., Pamięć (nie)ulotna, w: Architektura \& Biznes 11(340)/2020, Kraków 2020, s. 104-117.

\section{Discovering layers of history. Auschwitz Jewish Center "Oshpitzin" and The Great Synagogue Memorial Park in Oświęcim}

Summary: The article presents the history of the creation of two projects - the Auschwitz Jewish Center "Oshpitzin" and the Great Synagogue Memorial Park in Oświęcim from the perspective of a designer. The projects are discussed in broader contexts - architectural, urban, historical and cultural. The design assumptions, references and inspirations are presented in detail, as well as the rich and complicated history of specific places. The presented projects can be an example of incorporating contemporary architectural solutions into the historical urban fabric.

Keywords: architecture, urban planning, art, history, cultural heritage 